\title{
Türkçe Dersinde Yaratıcı Drama Yöntemine Dayalı Yaratıcı Yazma Çalışmalarının Yazmaya Yönelik Tutuma Etkisi
}

\author{
Fatma SUSAR KIRMIZI.
}

Pamukkale Üniversitesi

Özet

Bu araştırmanın amacı, Türkçe dersinde Yaratıcı Drama Yöntemine dayalı Yaratıcı Yazma çalışmalarının yazmaya yönelik tutuma etkisini ortaya koymaktır. Araştırmada, ön test, son test kontrol gruplu deney deseni kullanılmıştır. 68 ögrenciyle (kız=37; erkek=32) yapılan çalışma, 2007-2008 eğitim-ögretim yılında, Türkçe dersinde 5. sinıflarda, 1 deney grubu, 1 kontrol grubuyla gerçekleştirilmiştir. Deney grubu 32 (Kız=18, Erkek=14), kontrol grubu ise 36 ögrenciden (Kız=19, Erkek=18) oluşmaktadır. Deney grubunda Yaratıcı Drama Yöntemine dayalı Yaratıcı Yazma, kontrol grubunda ise Türkçe Dersi Öğretim Programı uygulanmıştır. Araştırma, Denizli/merkez ilçede bir ilköğretim okulunda, altı hafta boyunca devam etmiştir. Araştırmanın verileri "Yazmaya Yönelik Tutum Ölçeği (YAYTÖ)" ile toplanmıştır. Verilerin çözümlenmesinde t-testi kullanılmıştır. Araştırmada şu sonuçlara ulaşılmıştır: 1. Yazmaya yönelik tutuma ilişkin olarak son testlerde deney ve kontrol grupları arasinda, deney grubu lehine önemli bir fark bulunmaktadır. 2. Yazmaya yönelik tutuma ilişsin olarak deney grubunun ön ve son testleri arasinda önemli bir farklllık elde edilmiştir. 3. Yazmaya yönelik tutuma ilişkin olarak kontrol grubunun ön ve son testleri arasında da önemli bir farklllık elde edilmiştir.

Anahtar sözcükler: Türkçe Öğretimi, Yaratıcı Drama, Yaratıcı Yazma, Yazmaya Yönelik Tutum, Illkögretim.

\begin{abstract}
The aim of this study is to put forward the effect of Creative Writing efforts based on the Creative Drama Method on the writing attitude in Turkish courses. In the study, we used pretest, post-test control group experiment design. In the study, we had worked with 68 students $($ Female $=37 ;$ Male $=32)$ in 5th Grades for Turkish courses with 1 experiment group and 1 control group in the 2007-2008 school year. There were 32 students $($ Female $=18 ;$ Male $=14$ ) in the experiment group, and 36 students (Female=19; Male=18) in the control group. We arranged the Creative Writing based on the Creative Drama Method in the experiment group, and Turkish Curriculum in the control group. The study lasted six weeks in a primary school in Denizli city centre. The data obtained by "the Scale of Writing Attitude (SWA) and t-test was used for the analysis of the data. In the study we found the following conclusions: 1. for the writing attitude, in the post-tests, we found a significant difference between the experiment and control groups in favor of the experiment group. 2. For the writing attitude, we found a significant difference between pretests and posttests of the experiment group. 3. Also, for the writing attitude, we found a significant difference between pretests and posttests of the control group.
\end{abstract}

Keywords: Teaching Turkish, Creative Drama, Creative Writing, Writing Attitude, Primary Education.

· Yrd. Doç. Dr. Pamukkale Üniversitesi, Eğitim Fakültesi, İlköğretim Bölümü, Sınıf Öğretmenliği Ana Bilim Dal1, e-posta: fatmas_30@yahoo.com 


\section{Giriş}

"Yaratıcı Drama, grup çalışması içerisinde, bireylerin bir yaşantıyı ya da bir olayı kendi deneyimlerini de işin içine katarak eylemlerinde oynayarak canlandırması ve anlamlandırmasıdır" (Adıgüzel, 2006: 23). "Yaratıcı Drama, doğaçlama, rol oynama vb. tiyatro ya da drama tekniklerinden yararlanılarak, bir grup çalışması içinde, bireylerin bir yaşantıyı, bir olayı, bir fikri, kimi zaman bir soyut kavramı ya da bir davranışı, eski bilişsel örüntülerin yeniden düzenlenmesi yoluyla ve gözlem, deneyim, duygu ve yaşantıların gözden geçirildiği “oyunsu" süreçlerde anlamlandırılması, canlandırılmasıdır" (San, 2002: 81; San, 1999: 267). Yaratıcı Drama'da katılım, birliktelik ve paylaşım önemlidir. Drama etkinlikleri bir grup çalışmasıdır ve katılımda gönüllülük esastır (Adıgüzel, 2002; Aksarı, 2005). Öğrenme sürecine çocuğun etkince katılması için duygularını, düşlem gücünü, imgeleme yetisini, imgesel düşünmeyi ve hatta düşlerini de devreye sokabilmesi gerekir. Yaratıcı Drama çalışmaları bu değerlerin öğrenme süreçlerine katılmasını olanaklı kılmaktadır (San, 2002: 59). Okvuran (2002: 223) "Yaratıcı Dramanın tüm eğitim kademelerinde ve her yaştan insana uygulanabilecek yaratıcı drama çalışmaları eğitimin sıkıcı kalıplarını kırarak, çağdaş eğitim sistemiyle bütünleştirilebilir ve kendini geliştirme gereksinimi ve heyecanı duyan öğretmen ve öğrenciler yaratabileceğini” belirtmektedir (Akt. Adgüzel, 2002: 39-46).

Yaratıc1 Drama edilginlik yerine katılımcı olmayı gerektirir. Yaratıcı Dramayla birey, yetilerini keşfeder, kendine güveni artar, kendine güven ve saygı geliştirir, bağımsız karar verebilme becerisi kazanır ve yaşamda karşılaşabileceği değişik durumlara hazırlanır. Yaratıcı Drama hem kişisel, hem sosyal gelişimi sağlarken yaratıcılık ve farklı düşünebilme becerisini de ortaya çıkarmaktadır. Bu anlayışla paralel bir özellik gösteren Yaratıcı Yazma Yaklaşımı da bu araştırmanın diğer boyutunu oluşturmaktadır. Diğer taraftan Yaratııı Drama çalışmalarında, yazma çalışmalarından sıklıkla yararlanılır. Masal, şiir ve öykülerden pek çok biçimde yararlanılırken, yeni öyküler yaratma, var olan öyküden yararlanma, masaldan yola çıkarak yaratıcı düşünceyi geliştirme gibi etkinliklere yer verilmektedir.

Yazma; duyguların, düşüncelerin, isteklerin, tasarıların, yazılı olarak ifade edilmesidir. Yazma bilgiden çok beceri gerektirir. Bu beceriler ise uygulama ile gelişir (Calkins, 1986; Graves 1983; Öz, 2006). Ustaca yazma çok boyutlu bir beceridir ve yazma isteği gerektirir. Diğer taraftan ustaca yazma sıkı çalışma ve uzun yıllar boyunca uygulama gerektiren bir süreçtir. Birçok öğrenci düşüncelerini açık bir şekilde yazmada zorlanırlar (Applebee, Langer\&Mullis, 1986; Ganopole, 1988; Collins\&Cross, 1993; Collins \& Parkhurst, 1996). Yazma çalışmaları okullarda geleneksel bir yapı içerisinde sürdürülmektedir. Buna bağlı olarak yazı yazma çocuklar tarafından pek cazip bir etkinlik olarak da görülmez. Bunun nedenleri arasında, yazı yazarken çoğu kez kurallara bağlı kalma, kağıt temizliği, yazının düzgün 
yazılması, dilbilgisi kurallarına uygunluk gibi sıkı kurallar sıralanabilir. Bu tür etkinlikler, çocukların dikkatlerini yazının içeriğinden çok şekle yöneltmekte ve çocukların yazılarının aynı özelliklerde olmasını zorunlu kılmaktadır (Oral, 2003). Çocukların hayal gücünü ve yaratıcılığını geliştirmek hep göz ardı edilmektedir. Sıkıcı ve anlamsız kurallar arasında boğulan çocuk çareyi yazma çalışmalarından kaçmakta bulmaktadır.

Tompkins (1982) çocukların yaratıcı öyküler yazması için yedi neden sıralamaktadır: 1) eğlenmek; 2) sanatsal yönü olan ifadeyi geliştirmek; 3) yazmanın değer ve işlevini açıklamak; 4) hayal gücünü geliştirmek; 5) düşüncelerini açıklamak; 6) kendini tanıtmak için araştırmak 7) yazmak, okumak ve öğrenmek için.

Yazmaya yönelik var olan geleneksel bir bakış açısı da "yazmanın bireysel bir etkinlik olarak" görülmesidir. Ancak son yıllardaki eğilim bu bakış açısından oldukça uzaktır. Dyson'a göre (1995) yazma bireysel bir etkinlikten çok sosyal etkileşim gerektiren bir durumdur. Rayers (1987) ise yazmaya yeni başlayan genç insanların, yazma sürecini hızlandırmak için “paylaşımcı yazma” yapması gerektiğini savunmaktadır. Böylece öğrenen, yazmaya yönelik teknik bakış açısını daha iyi geliştirecek ve sorumluluklarının daha fazla farkına varacaktır. Sutherland ve Topping'e (1999) göre yazmadaki sosyal etkileşim, Vygotsky'nin görüşlerinin temelini oluşturan bir düşüncedir. Sosyal etkileşim yazının niteliğini olumlu yönde arttırmaktadir.

Yazma başarısını etkileyen birçok etken bulunmaktadır. Öğrencinin yazmaya yönelik isteğinin güçlendirilmesi yalnızca sınıf içinde kullanılan yöntemle açıklanamaz. Güçlü bir yazma isteği, öğrencinin yazma becerisini kullanabilmesi kadar önemlidir. Yazmaya yönelik olumlu bir isteğe sahip olmak aynı zamanda yazmaya yönelik olumlu bir tutum gerektirmektedir. Kağıtçıbaşı'na göre (1999) bir bireyin tutumları gözle görülemez, ancak, davranışlarına bakılarak tutumuna yönelik bir fikir sahibi olunabilir. Tutumlar, kendileri gözlenemeyen fakat gözlenebilen bazı davranışlara yol açtığı varsayılan eğilimlerdir.

Yazma becerisindeki eksiklikler büyük bir olasılıkla yazmaya yönelik tutum eksikliği ile ilgilidir. Diğer nedenler ise öğrencinin düşük sosyo ekonomik statüden kaynaklanan farklı yaşam biçimi, sağlık sorunları ve yetersiz okuma alışkanlığı olabilir. Yazmaya yönelik tutum, yazma başarısını arttırmada oldukça etkilidir (Bartscher, Lawler, Ramirez and Schinault, 2001).

İlginç konular öğrencilerin yazmaya yönelik isteğini arttırabilir. Farklı ve özgün yazma çalışmaları öğrencilerin düşünme becerilerinin gelişmesinde de oldukça etkilidir. Bu çalışmalar öğrencilerin, akademik yaşamda da yazmaya yönelik tutumlarını etkileyecektir (Colantone, Cunnigham-Wetmore\&Dreznes, 1998). 
$\mathrm{Bu}$ araştırmada son yıllarda ortaya çıkan, genel eğilim doğrultusunda yazma çalışmaları kapsamında, sosyal etkileşimden yararlanılmaya çalışılmıştır. Bu düşünceden hareketle Yaratıcı Drama Yöntemi ve Yaratıcı Yazma Yaklaşımı arasında ilişki kurulmaya çalışılmıştır. Yaratıcı Drama Yöntemi hem de Yaratıcı Yazma yaklaşımı sosyal etkileşim gerektiren uygulamalar içermektedir. Ortak özellikleri çok fazla olan Yaratıcı Drama Yöntemi ve Yaratıcı Yazma Yaklaşımının yazmaya yönelik tutuma etki edip etmediği de araştırmanın temel noktası olarak kabul edilmiştir.

\section{Araştırmanın Amacı ve Önemi}

Ülkemizde yüksek eğitim kademelerinden mezun olmuş bireylerin bile kendini yazılı olarak ifade etmekten kaçındığı görülmektedir. Bunun temel nedenlerinden birisi de ilkokul yıllarından yüksek öğretime kadar uzanan yazma çalışmalarındaki sıkı eğitim anlayışıdır. Yazma çalışmaları sıkıcı birtakım kurallar kapsamında gerçekleştirilmektedir. Yazma çalışmaları denince çoğunlukla akla gelenler kağıt düzeni, açıklanması zor atasözleri ve özlü sözler, yazım kurallarına uygunluk gibi durumlardır. Yazma çalışmaları öncesinde yapılan eğlenceli etkinlikler ya da yaratıcılık gerektiren konular çoğunlukla sınıf içi çalışmalarda yer almaz. Oysa yazma çalışması, sıkı kurallarla bağlanamayacak kadar kapsamlı hayal gücünü geliştirecek kadar da yaratıcı olan özel bir çalışma alanıdır. Yazma çalışmalarının etkin bir şekilde yapılması öğrencinin kendini farklı bir şekilde ortaya koymasında oldukça etkili olabilir. 2005 yılından itibaren uygulanan, yeni yaklaşım ve yöntemler içeren MEB Türkçe programıyla artık yazmadan korkmayan, yazmaya yönelik olumlu bir bakış açısı kazanmış bireylerin yetiştirilmesi amaçlanmaktadır. Ancak programın bu konuda ne kadar yeterli olduğunun da sorgulanması gerektiği göz önünde tutulması gereken bir gerçektir.

Yazma becerisinin geliştirilmesi için öncelikle öğrencinin yazmadan zevk alması gerekmektedir. $\mathrm{Bu}$ da yazmayla ilgili yaratıcı ve eğlenceli çalışmalar yapılığında gerçekleşebilir. Böylece yaşam boyu yazı yazma alışkanlığı da kazandırılabilir. Yazma becerisinin geliştirilmesi, farklı yöntem ve etkinliklere yer verilmesini gerektirmektedir. $\mathrm{Bu}$ anlayıştan hareketle yapılan araştırmada, hem yaratıcılık gerektiren, öğrenciyi etkin k1lan ve kendini ifade etmesini sağlayan bir yönteme hem de farklı düşünmeyi sağlayan bir yazma yaklaşımına yer verilmiştir. Bu sayede öğrencinin yazmaya yönelik olumlu tutumlar geliştirip geliştiremeyeceği de tespit edilmek istenmiştir.

Yapılan bu çalışmanın, bundan sonra yapılacak olan yazma çalışmaları ile ilgili akademik araştırmalara katkı getireceği düşünülmektedir. Bunun dışında 2005-2006 öğretim yılından itibaren tüm ülkede uygulanan Türkçe programının da yazmaya yönelik tutum geliştirme konusunda ne kadar etkili olduğu sorgulanmak istenmiştir. Zaman içerisinde bu programın aksayan yönlerini düzeltmek amacıyla program geliştirme çalışmaları yapılacağı varsayılırsa, 
araştırma sonuçlarının bu çalışmalara da katkı getireceği düşünülmektedir. Kontrol grubunda ülkede şu anda uygulanmakta olan programın takip edildiği düşünüldüğünde, bu grubun değerlendirmelerine yönelik olarak elde edilen sonuçlar 2005-2006 MEB Türkçe programına ilişkin değerlendirmelere de olanak sağlayacaktır.

Bu araştırmanın amacı; İlköğretim 5. sınıflarda, Türkçe dersinde Yaratıcı Drama Yöntemine dayalı Yaratıcı Yazma çalışmalarının yazmaya yönelik tutuma etkisini ortaya koymaktır.

\section{Alt Problem}

$\mathrm{Bu}$ araştırmanın alt problemi, belirlenen amaç doğrultusunda şu şekilde ortaya konulmuştur:

1. Yaratıcı Drama Yöntemine dayalı Yaratıcı Yazma ve Türkçe Dersi Öğretim Programıyla yapılan öğretim öğrencilerin yazmaya yönelik tutumları üzerinde anlamlı faklılıklar oluşturmakta midır?

Araştırmada şu kısaltmalar yer almaktadır: YAYTÖ: Yazmaya Yönelik Tutum Ölçeği, YADYAY: Yaratıcı Drama Yöntemine Dayalı Yaratıcı Yazma Grubu, TÜPÖ: Türkçe Dersi Öğretim Programıla Öğrenme Grubu.

\section{Yöntem}

Çalışmanın alt problemini araştırmak amacıyla ön test, son test kontrol gruplu deney deseni kullanılmıştır (Büyüköztürk, 2002; Karasar, 2005).

\section{Örneklem}

Araştırma, 2007-2008 eğitim-öğretim yılı birinci döneminde, Denizli merkez ilçede, ilköğretim beşinci sınıflarda gerçekleştirilmiştir. Milli Eğitim Müdürlüğünden merkez ilçede yer alan okulların ve bu okulların sosyo-ekonomik düzeyi, bulunduğu semtler, öğrencilerin devam durumu vb. özellikler de istenmiştir. Bu verilerden yola çıkılarak orta sosyo-ekonomik düzeyde yer alan okullar belirlenmiş ve seçkisiz yöntemle bir tanesi tespit edilmiştir. Okul yöneticileri ile yapılan görüşmeler sonucunda da bu okulda çalışma yapılmasına karar verilmiştir. Katılımcıların yer aldığı iki beşinci sınıf şubesi deney ve kontrol grubu olarak yine seçkisiz bir yolla belirlenmiştir. Deney grubunda Yaratıcı Drama Yöntemi, kontrol grubuna ise 2005-2006 Eğitim-Öğretim yılı Türkçe programında yer alan yöntem, teknik ve etkinlikler uygulanmıştır. Deney grubu $32\left(\mathrm{~K} ı=18\right.$, Erkek=14), kontrol grubu ise 36 ögrenciden $\left(\mathrm{K}_{1 z}=19\right.$, Erkek=18) oluşmaktadır. Altı hafta süren çalışmaya her hafta üç ders saati (45 dakika x 3) ayrılmıştır. Aynı günde yapılan üç saatlik (135 dakika) her çalışma bir oturum olarak kabul edilmiştir. Uygulama sırasında 5. sınıf-Türkçe ders kitabında (Karafilik, Değirmenci, Bilkan ve Özdem, 2007) yer alan "Yenilikler ve Gelişmeler” temasının "Büyük Başarı, Hayatımızın 
Işıyan Yanı, Robot ve Masal, Robot Karıncalar” isimli metinlerine yönelik etkinliklere yer verilmiştir.

\section{Veri Toplama Aracı}

Araştırmada, araştırmacı tarafindan geliştirilen ve "ilköğretim okullarında 4. 5. sınıf öğrencilerinin yazmaya yönelik tutumlarını" belirlemeyi amaçlayan "Yazmaya Yönelik Tutum Ölçeği (YAYTÖ)" kullanılmıştır.

Ölçeğin geliştirilmesinde, alan yazın taraması ve öğrencilerin görüşlerinden çıkarılan sonuçlar maddeler haline getirilmiştir. Maddelere yönelik uzman görüşü alınması amacıyla Denizli ilinin çeşitli ilköğretim okullarında, 4. ve 5. sınıfta görev yapan dört sınıf öğretmeni ve değişik üniversitelerde görev yapan (Eğitim Bilimleri Bölümü, Türkçe Eğitimi Bölümü ve İlköğretim Bölümü) 8 öğretim elemandan görüş alınmıştır. Ölçeğin uygulanabilirliği, ifadeleri, dil kurallarına uygunluğu açısından alınan uzman görüşü önerileri doğrultusunda ölçek maddeleri yeniden düzenlenmiştir. Bütün bu aşamalardan sonra ölçek maddelerinin sayısı elenerek 52'ye indirilmiştir. Bu maddelere ilişkin öğrencilerin katılma düzeylerini belirlemek amacıyla Likert tipi ölçekle "Tamamen Uygun, Oldukça Uygun, Kısmen Uygun, Çok Az Uygun, Hiç Uygun Değil" şeklinde beşli derecelendirme yapılmıştır.

52 maddelik ölçeğin öndeneme çalışması Denizli İli merkezinde yer alan, çeşitli resmi ve özel ilköğretim okullarının 4. (n=122) ve 5.(n=136) sınıflarında, 2007-2008 eğitim öğretim yılı, güz döneminde gerçekleştirilmiştir. $258 \quad(\mathrm{k} ı \mathrm{z}=145$, erkek113) kişi üzerinden yapılan değerlendirmede olumlu soru maddeleri için katılma derecesine beşten, olumsuz soru maddeleri için ise birden başlanmıştır.

YAYTÖ’nün yapı geçerliliğini belirlemek amacıyla, deneme çalışmasından elde edilen verilere faktör analizi uygulanmıştır. Deneme çalışmasından elde edilen verilere faktör analizi uygulamadan önce, faktör analizi uygulanmasının mümkün olup olmadığı araştırılmıştır. Bunun için KMO (Kaiser-Meyer-Olkin) değeri referans olarak alınmıştır. YAYTÖ'nün ilk analiz sonuçlarına göre ölçeğin KMO değeri 0,90 bulunmuştur. Verilerin faktör analizine uygunluğu için KMO katsayısının 0,60'dan yüksek olması beklenir. Bu çalışmadan elde edilen değere göre örneklemin yeterli olduğu sonucuna varılmıştır (Pallant, 2001). Verilerin çok değişkenli normal dağılımdan gelip gelmediği Bartlett küresellik testi (Bartlett test of sphericity) değeri ile incelenmiştir. Çalışmanın verilerine uygulanan Bartlett küresellik testi sonucuna göre Approx. Chi-Square $=5864,589$ olarak bulunmuştur. Bartlett küresellik testinin sonucu 0,05 düzeyinde anlamlı çıkmıştır $(\mathrm{p}=0,000)$. Bartlett testinin anlamlı çıkması verilerin faktör analizi için uygun olduğunu gösterir. Buna göre verilerin faktör analizi için uygun olduğu söylenebilir. Verilere döndürülmüş faktör çözümlemesi yapılmıştır. Sonuçta birden fazla faktörde yer alan ve 0,50'nin altında olan maddeler ölçme aracından çıkarılmış ve aynı işlemler tekrarlanarak analiz 
gerçekleştirilmiştir. 18 madde elendikten sonra kalan 34 madde ile ölçek oluşturulmuştur. Maddelere ilişkin faktör öz değerleri de 0,50 ila 0,86 arasında değişim göstermektedir. Cronbach Alpha güvenirlik katsayısının 0,90 olduğu belirlenmiştir. Her bir öğrencinin ölçekten alabileceği ağırlıklı ham puan en az 34, en çok ise 170 'tir. Toplam puanın yüksek olmasının, öğrencilerin yazmaya yönelik tutumlarının olumlu olduğunun, düşük olması da tutumlarının olumsuz olduğunun göstergesi olarak yorumlanmaktadır (Yazmaya Yönelik Tutum Ölçeği İçin Bkz. EK-2).

\section{İşlem}

Altı oturumda yer alan Yaratıcı Drama ve Yaratıcı Yazma etkinlikleri (Etkinlik örneği için bkz. EK-1) aynı zamanda liderlik eğitimi de almış olan araştırmacı tarafından hazırlanmış ve uygulanmıştır. Çalışmaların rahat ve geniş bir alanda yapılması gerektiğinden genellikle okulun tiyatro salonunda çalışılmıştır. Yazma çalışmaları ise etkinliğin özelliğine göre zaman zaman bu salonda zaman zaman ise sınıfta gerçekleştirilmiştir. Orta sosyo-ekonomik düzeydeki bir okulda gerçekleştirilen çalışma süreci içerisinde, yeni Türkçe programına da uygun bir şekilde Türkçe eğitiminin alanları olan dinleme, konuşma, okuma, yazma, görsel okuma ve görsel sunu becerilerinin bir bütün olduğu ilkesinden hareket edilmiş, günlük planlar ve çalışma yaprakları bu anlayış içerisinde hazırlanmıştır. Ancak araştırmanın amacı doğrultusunda yazma etkinlikleri, Yaratıcı Yazma Yaklaşımına uygun bir şekilde düzenlenmiştir. Yaratıcı Drama çalışmalarında istasyon tekniği, ritim çalışması, fotoğraf kullanma, doğaçlama, resim yapma, devinim tiyatrosu, donuk imgeler, şiiri masallaştırma, televizyon programı yapma, bilinç koridoru gibi teknik ve etkinliklere yer verilmiştir. Oturum sonlarında etkinlik sürecinin değerlendirilmesine ilişkin çalışmalar yapılmıştır. Yapılan planlar üç ayrı aşamayı kapsamaktadır: 1. Hazırlık-Isınma Çalışmaları, 2. Canlandırma, 3. Değerlendirme-Tartışma (Adigüzel, 2006).

Yaratıcı yazma ile etkinliklerin gerçekleştirilmesinde grupla birlikte öykü yazmaya, slogan yazmaya, kişisel öykülere, bilim kurgu yazılarına, pencere tekniği ile şiir yazmaya, diyalog yazmaya, fotoğraf eşliğinde yazmaya, duvar yazıları yazmaya, öykü karakteri oluşturmaya, yeni deyim ve atasözleri oluşturmaya, anahtar kelimelerle çalışmaya yer verilmiştir. Yaratıcı Yazma etkinlikleri düzenlenirken öğrencileri neşelendiren, düşündüren, hayal gücünü harekete geçiren, problem çözme becerilerini geliştiren, sentez ve yorum yapmalarına izin veren çalışmalara yer verilmeye gayret edilmiştir. Uygulamalarda yazılı ürünlerle ilgili dönüt verilirken, öğrenciler arasında kıyaslama yapmaktan, olumsuz sözler kullanmaktan kesinlikle uzak durulmuş, istenilen ölçütleri taşımak konusunda çok yetersiz yazılar bile yapıcı cümlelerle yorumlanmıştır. Yazma çalışmalarında kağıdın temizliği, yazının düzgünlüğü gibi şekille ilgili uyarılara fazla yer verilmemeye, öğrencilerin yazmaya yönelik olumsuz tutum geliştirileceği ve dikkatlerinin 
dağılacağı düşüncesiyle özen gösterilmiştir (Yaratıcı Drama ve Yaratıcı Yazma Etkinlik Örneği için Bkz. EK-1).

\section{Verilerin Çözümlenmesi}

$\mathrm{Bu}$ araştırmada, Yazmaya Yönelik Tutum Ölçeğinin geçerlilik ve güvenirliklerinin sağlanması ve verilerin çözümlemesi için faktör çözümlemesinde madde ölçek korelasyonu, Cronbach's Alpha ve t-testi istatistik teknikleri kullanılmıştır.

\section{Bulgular}

Araştırmanın alt problemi "Yaratıcı Drama Yöntemine dayalı Yaratıcı Yazma ve Türkçe Dersi Öğretim Programıyla yapılan öğretim öğrencilerin yazmaya yönelik tutumları üzerinde anlamlı faklılıklar oluşturmakta mıdır?" şeklinde belirlenmişti. Bu bölümde elde edilen veriler, alt probleme uygun olarak çözümlenmiş ve tablolar halinde verilerek yorumlanmıştır. Alt probleme yanıt vermek amaciyla hem deney hem de kontrol grubuna YAYTÖ ön test olarak uygulanmıştır. Böylece her iki grubun yazmaya yönelik tutumlarının birbirine denk olup olmadığı da kontrol edilmek istenmiştir. YADYAY ve TÜPÖ Gruplarının ön testleri arasındaki farkın önemli olup olmadığına ilişkin bulgular Tablo 1'de sunulmaktadır.

\section{Tablo 1}

Deney ve Kontrol Gruplarının "Yazmaya Yönelik Tutumlarına" İlişkin Ön Test Ölçümlerinin Karşılaştırılması (t-testi)

\begin{tabular}{lcccccc}
\hline \multicolumn{1}{c}{ Gruplar } & $\mathbf{n}$ & $\overline{\mathbf{X}}$ & Ss & sd & t & Önem Denetimi \\
\hline YADYAY & 32 & 98,56 & 14,23 & 66 & 0,65 & $0,616^{*}$ \\
TÜPÖ & 36 & 101,50 & 14,49 & & & $\mathrm{P}>0,05$ Fark önemsiz \\
\hline
\end{tabular}

Tablo 1'e göre YADYAY $(\overline{\mathrm{X}}=98,56)$ ve TÜPÖ $(\overline{\mathrm{x}}=101,50)$ gruplarının ön test ortalamaları arasında yapılan karşılaştırmada anlamlı bir fark olmadığı görülmüştür $\left[\mathrm{t}_{(66)}=0,65, \mathrm{p}>0,05\right]$. Elde edilen bu sonuç doğrultusunda deney ve kontrol grubunun yazmaya yönelik tutumlar açısından birbirine denk gruplar olduğu belirlenmiştir. Ön testlerden elde edilen bu sonuç, araştırmaya söz konusu gruplarla devam edilmesinde temel etkenlerden birisi olarak kabul edilmiştir. YAYTÖ'nün son testlerine göre deney grubu ve kontrol grubu arasında önemli bir farkın olup olmadığını belirlemek amacıyla t-testi çözümlemesi yapılmış, elde edilen sonuçlar Tablo 2'de sunulmuştur.

\section{Tablo 2}

Deney ve Kontrol Gruplarının "Yazmaya Yönelik Tutumlarına” İlişkin Son Test Ölçümlerinin Karşılaştırılması (t-testi)

\begin{tabular}{ccccccc}
\hline Gruplar & $\mathbf{n}$ & $\overline{\mathbf{X}}$ & Ss & sd & t & Önem Denetimi \\
\hline YADYAY & 32 & 123,50 & 20,37 & 66 & 2,96 & $0,004^{*}$
\end{tabular}


Tablo 2'de YADYAY ve TÜPÖ gruplarının son test ölçümleri arasındaki karşılaştırma sonuçları verilmektedir. Yazmaya yönelik tutum konusunda elde edilen ölçme sonuçları doğrultusunda YADYAY $(\overline{\mathrm{X}}=123,50)$ ve TÜPÖ $(\overline{\mathrm{X}}=110,13)$ gruplarının son testleri arasında anlamlı bir farklılık olduğu tespit edilmiştir $\left[\mathrm{t}_{(66)}=2,96, \mathrm{p}<0,05\right]$. Bu duruma göre YADYAY için planlanıp uygulanan sürecin öğrencilerin yazmaya yönelik tutumlarını geliştirmede, TÜPÖ'de uygulanan Türkçe Öğretimi programı etkinliklerinden daha etkili oldu olduğu söylenebilir. Deney grubunda uygulanan Yaratıcı Dramaya dayalı Yaratıı Yazma yaklaşımı öğrencilerin grup içi etkileşimini temele almıştır. Bu etkileşim öğrencilerin yaratıcılık ve hayal gücünü harekete geçirecek bir şekilde düzenlenmiş ve uygulanmıştır. Bu sürecin deney grubunda yazmaya yönelik olumlu bir bakış açısı kazandırma konusunda etkili olduğu belirlenmiştir. YADYAY grubundaki öğrencilere ön test ve son test olarak uygulanan YAYTÖ'nün aritmetik ortalaması, t değeri ve $\mathrm{p}$ değeri hesaplanmış, testlerin ortalamaları arasındaki farkın önemli olup olmadığını anlamak için de t-testi yapılmıştır. Elde edilen sonuçlar Tablo 3'te sunulmaktadır.

\section{Tablo 3}

Deney Grubunun "Yazmaya Yönelik Tutumlarına" İlişkin Ön Test-Son Test Ölçümlerinin Karşılaştırılması (t-testi)

\begin{tabular}{cccccccc}
\hline Grup & Testler & $\mathbf{n}$ & $\overline{\mathbf{X}}$ & Ss & Sd & $\mathbf{t}$ & Önem Denetimi \\
\hline YADYAY & Ön Test & 32 & 98,56 & 13,22 & 62 & 5,80 & $0,000^{*}$ \\
& Son Test & 32 & 123,50 & 20,37 & & & $\mathrm{P}<0,05$ Fark önemli \\
\hline
\end{tabular}

Tablo 3'te yazmaya yönelik tutumlara ilişkin yapılan ön test ve son test ölçümlerinin t-testi sonuçları görülmektedir. YADYAY grubunun son test ortalamasının $(\overline{\mathrm{X}}=123,50)$, ön test ortalamasından ( $\bar{X}=98,56)$ daha yüksek olduğu ve her iki ölçüm arasında önemli bir fark elde edildiği belirlenmiştir $\left[\mathrm{t}_{(62)}=5,80, \mathrm{p}<0,05\right]$. Araştırma sürecinin başında belirlenen kazanımlara ulaşmak için deneysel çalışma süresince, Yaratıcı Drama Yöntemine dayalı Yaratıcı Yazma yaklaşımı kapsamında özgün etkinliklere yer verilmiştir. Bu etkinlikler sırasında öğrenciler, programda yer alan uygulamalardan farklı yaratıcı çalışmalarla desteklenmiştir. Yapılan çalışmalarda hayal kurma ve hayallerinden yola çıkarak yazma, grupla birlikte yazılar yazma, fotoğraflardan yola çıkarak yazma, sıra dışı durumlar hakkında yazma gibi çalışmalar yapılmıştır. Söz konusu etkinlikler yapılırken de öğrencilerin yaratıcılığını harekete geçirmeye yardımcı çalışmalardan yola çıkılmıştır. Öğrencilerin geçirmiş olduğu bu eğitsel süreç ise yazmaya yönelik tutumlar için uygulanan ön test ve son testler arasında anlamlı bir farklılık çıkmasında etkili olmuştur. Elde edilen bu sonuç doğrultusunda, Yaratıcı Drama Yöntemine dayalı Yaratıcı Yazma çalışmalarının öğrencilerin yazmaya yönelik tutumlarını olumlu yönde değiştirdiği söylenebilir. TÜPÖ Grubunda ön ve son test olarak uygulanan YAYTÖ’nün 
ortalamaları arasında önemli bir farkın olup olmadığııı belirlemek amacıyla t-testi çözümlemesi yapılmış elde edilen sonuçlar Tablo 4'te verilmiştir.

\section{Tablo 4}

Kontrol Grubunun "Yazmaya Yönelik Tutumlarına" İlişkin Ön Test-Son Test Ölçümlerinin Karşılaştırılması (t-testi)

\begin{tabular}{cccccccc}
\hline \multicolumn{1}{c}{ Grup } & Testler & $\mathbf{n}$ & $\overline{\mathbf{X}}$ & $\mathbf{S s}$ & $\mathbf{S d}$ & $\mathbf{t}$ & Önem Denetimi \\
\hline TÜPÖ & Ön Test & 36 & 101,50 & 14,49039 & 70 & 2,34 & $0,02^{*}$ \\
& Son Test & 36 & 110,13 & 16,73688 & & & $\mathrm{P}<0,05$ Fark önemli \\
\hline
\end{tabular}

Tablo 4'te TÜPÖ grubunun yazmaya yönelik tutumlarına ilişkin ön test ve son test karşılaştırmaları verilmektedir. TÜPÖ grubunun, son test ortalamasının $(\overline{\mathrm{X}}=110,13)$, ön test ortalamasından $(\overline{\mathrm{x}}=101,50)$ önemli bir farkl11ık oluşturacak şekilde yüksek olduğu görülmektedir $\left[\mathrm{t}_{(70)}=2,34, \mathrm{p}<0,05\right] \quad$ Kontrol grubunda 2004 beşinci sınıf Türkçe öğretim programına uygun bir eğitim süreci izlenmiştir. Yapılan etkinlikler bu programa uygun bir şekilde gerçekleştirilmiş, dolayısıyla da programda yer alan çağdaş uygulamalara da yer verilmiştir. Örneğin kavram haritası, beyin firtınası, 5N 1K, balık kılçı̆̆ı, hikaye haritası gibi çağdaş uygulamalara da yer verilmiştir. Bu çalışmalar daha çok bireysel etkinlikler şeklinde uygulanmıştır. Kontrol grubunda, grup çalışmalarına deney grubunda olduğu kadar yer verilmemiştir. Yapılan bu çalışmalar kontrol grubunun yazmaya yönelik tutumlarına ilişkin uygulanan ön ve son testler arasında anlamlı farklılıklar elde etmede etkili olmuştur. Elde edilen veriler 1şı̆̆ında 2004 Türkçe öğretimi programının da yazmaya yönelik olumlu tutum geliştirmede etkili olduğu söylenebilir. Ancak YADYAY ve TÜPÖ gruplarının son test ortalamaları dikkatle incelenecek olursa deney grubunun yazmaya yönelik tutumunun oldukça yüksek olduğu gözden kaçmayacaktır. Diğer bir deyişle Yaratıcı Dramaya dayalı Yaratıcı Yazma Yaklaşımı olumlu tutum geliştirmede 2004 Türkçe programına göre daha etkilidir.

\section{Tartışma}

Yazmaya Yönelik Tutuma ilişkin olarak son testlerden elde edilen sonucuna göre, YADYAY ve TÜPÖ Grupları arasında farkın deney grubu lehine anlamlı çıktığı tespit edilmiştir. YADYAY grubunda yazmaya yönelik olumlu tutum geliştirmek amacıyla Yaratıcı Drama Yönteminin ve Yaratıcı Yazma Yaklaşımının farklı tekniklerine yer verilmiştir. Deney grubunda gerçekleştirilen öğrenme yaşantılarında Yaratıcı Drama yönteminin grup dinamiğinden yararlanılmış, zaman zaman bireysel zaman zaman grup etkinliklerine yer verilmiştir. Yaratıcı Drama ve Yaratıcı Yazmanın özelliklerine uygun bir şekilde hayal ve imgelem gücüne dayalı olarak gerçekleştirilen etkinliklerde, çocukların yaratıcıllı̆ı ortaya çıkarılmaya çalışılmıştır. Etkinliklerin uygulanmasında öğrenciler bireysel ya da grup halinde 
hayal kurmuşlar, oyun oynamışlar, farklı tekniklerle etkin bir öğrenme süreci geçirmişlerdir. Eleştirilme ve yanlış yapma kaygısından tamamen uzak olan öğrenciler yazma çalışmalarında kişisel düşüncelerini istedikleri gibi ortaya koyabilmişlerdir. Hatta, lider tarafından öğrencilere, "sizlere saçma bile gelse düşüncelerinizi yazmaktan çekinmeyin" önerisi sunulmuştur. Oturumlar süresince, farklı düşüncelerini dile getirmekten dolayı yargılanmayacağını bilen öğrenciler, sınırsız düşünmüş, geleneksel kalıpların dışına çıkmıştır. Çocuklar düşüncelerini istediği şekilde dile getirmiş ve istediği gibi yazı yazmıştır. Kağıtların kenarlarında bıraktıkları, üç santimlik boşluğun azlığı ya da çokluğu gibi nedenlerden dolayı eleştirilmeyeceğini düşünen öğrenci özgürce yazarak iç dünyasını yansıtmıştır. $\mathrm{Bu}$ durum öğrencilerin yazma çalışmalarından kaçmamasını ve yazmaya yönelik olumlu tutum geliştirmelerini sağlamıştır. Elde edilen sonuç doğrultusunda Yaratıcı Drama Yöntemine dayalı Yaratıcı Yazma çalışmalarının yazmaya yönelik olumlu tutum geliştirmede etkili olduğu söylenebilir.

Deney ve kontrol gruplarının yazmaya yönelik tutumlarına ilişkin ön ve son testler karşılaştırıldığında her iki grupta da son testler lehine bir önemli bir farklılık elde edilmiştir. Diğer bir deyişle kontrol grubunda yer alan öğrencilerin de yazmaya yönelik olumlu tutum geliştirdikleri tespit edilmiştir. Daha önce de belirtildiği gibi kontrol grubunda, beşinci sınıf MEB 2005-2006 Türkçe programı uygulamalarına yer verilmiştir. Dolayısıyla programın ruhuna uygun bir şekilde çağdaş uygulama ve etkinliklere yer verilmiştir. Balık kılçığı, kavram haritaları, $5 \mathrm{~N} \mathrm{1K}$, öykü haritaları vb. uygulamalar süreç içerisinde, bireysel ya da grup halinde gerçekleştirilmiştir. Bu durumun yazmaya yönelik olumlu tutum geliştirmede etkili olabileceği gözlerden kaçmamalıdır. Ancak bu noktada dikkat edilmesi gereken bir durum var ki o da deney grubunun son test ortalamasinin $(\overline{\mathrm{x}}=123,50)$ kontrol grubunun son test ortalamasından( $\overline{\mathrm{X}}=110,13)$ oldukça yüksek oluşudur. Deney grubunda yapılan çalışmalar, yazmaya yönelik tutumun, daha yüksek bir ortalama ile ortaya çıkmasını sağlamıştır. Kısacası yaratıcılık, hayal gücü, kendini özgürce ifade etme üzerine kurulu bir yazma anlayışı doğrultusunda gerçekleştirilen Yaratıcı Drama Yöntemine dayalı Yaratıcı Yazma çalışmaları Türkçe öğretimi programının uygulamalarından daha etkili olmuştur. Elde edilen sonuca göre yazmaya yönelik olumlu tutum geliştirmek yeni programla da mümkündür. Ancak ömür boyu yazma alışkanlığı geliştirmek Yaratıcı Drama ve Yaratıcı yazma çalışmalarıyla daha kolay geliştirilebilmektedir.

\section{Sonuç ve Öneriler}

Yazmaya yönelik tutuma ilişkin olarak son testlerde deney ve kontrol grupları arasında, deney grubu lehine önemli bir fark bulunmaktadır. Yazmaya yönelik tutuma ilişkin olarak deney grubunun ön ve son testleri arasında önemli bir farklılık elde edilmiştir. Araştırmanın sonuçları doğrultusunda şu öneriler geliştirilebilir: Yazmaya yönelik olumlu tutum geliştirmek için 
Programda Yaratıcı Yazma ve Yaratıcı Drama etkinliklerine sıkça yer verilmelidir. Program Yaratıcı Yazma ve Yaratıcı Drama etkinliklerinin yeterliliği açısından yeniden gözden geçirilmelidir. Öğrenciler yazma çalışmalarında duygu ve düşüncelerini özgürce dile getirmek için teşvik edilmelidir. Yazma çalışmalarındaki öğrenciler için belirlenmiş zor ve yorucu kurallar gerektiğinde esnetilebilmelidir. Düşüncelerinin farklılığından dolayı öğrenciler yargilanmamalidir.

\section{Kaynaklar}

Adıgüzel, H.Ö. (2002). Biz düşlerimizi yaratıcı drama ile gerçek yapıyoruz. Yaratıcı Drama/1985- 1995/ Yazılar. 1. Cilt. Ankara: Naturel Kitap Yayıncılık.

Adıgüzel, H.Ö. (2006). Yaratıcı drama kavramı, bileşenleri ve aşamaları. Yaratıcı Drama Dergisi, 1,1, 14-27.

Aksarı, S. (2005). İlköğretimde günlük plan olarak drama önerileri. Ankara: Nobel Yayınları.

Applebee, A. N., Langer, J. A., \& Mullis, I. V. S. (1986). The writing report card: Writing achievement in American schools. Princeton, NJ: Educational Testing Service.

Bartscher, M. A., Lawler, K.E., Ramirez, A.J.\&Schinault, K.S. (2001). Improwing student's writing ability through journals and creative writing exercices. Master of arts action research project reports, Saint Xavier University, Chicago.

Büyüköztürk, Ş. (2002). Sosyal bilimler için veri analizi elkitabı: İstatistik, araştırma deseni, spss uygulamalarl ve yorumu. Ankara: Pegem Yayınc1lık.

Calkins, L. (1986). The art of teaching writing. Portsmouth, NH: Heinemann Educational Books.

Collins, N. D., \& Cross, T. L. (1993). Teaching the writing process to gifted and talented students. Gifted Child Today, 16(3), 22-23.

Collins, N. D., \& Parkhurst, L. (1996). Teaching strategies for gifted children in the regular classroom. Roeper Review, 18, 277-279.

Colantone, L., Cunnigham-Wetmore, M.\&Dreznes, J. (1998). Improwing creative writing. Research project reports, Saint Xavier University, Chicago.

Dyson, A.H. (1995). Writing children: reinventing the development of chilhood literacy. Written Communication, 12, 4-46.

Ganopole, S. J. (1988). Reading and writing for the gifted: A whole language perspective. Roeper Review, 11, 88-91.

Graves, D. (1983). Writing: Teachers and children at work. Portsmouth, NH: Heinemann Educational Books.

Kağıtçıbaşı, Ç. (1999). Yeni insan ve insanlar. (10. Baskı). İstanbul: Evrim Basın Yayın Dăğtım.

Karafilik, F., Değirmenci, G., Bilkan, N.\&Özdem, N. (2007). İlköğretim Türkçe ders kitabı 5. Ankara: Harf Eğitim Yayıncılık.

Karasar, N. (2005). Bilimsel araştırma yöntemi. (14. baskı). Ankara: Nobel Yayınc1lık.

Okvuran, A. (2002). Çağdaş İnsanı Yaratmada Yaratıcı Drama Eğitiminin Önemi ve Empatik Beceri Empatik Eğilim Düzeylerine Etkisi. Ankara: Ankara Üniversitesi Eğitim Bilimleri Fakültesi Yayınları. Aktaran: Adıgüzel. H.Ö. (2002). Yaratıcı drama/1985-1995/ yazılar. (1. cilt.). Ankara: Naturel Kitap Yayınc1lı.

Oral, G. (2003). Yine yazı yazıyoruz. Ankara: Pegema Yayıncılık.

Öz, F. (2006). Uygulamalı Türkçe öğretimi. Ankara: Anı yayıncılık. 
Pallant, J. (2001). SPSS Survival Manual. A Step-by-Step Guide to Data Analyysis Using SPSS for Windows. Philadelphia, PA.: Open University Press.

Rayers, C. (1987). Writing shoul be sharing. Reading, 2,12, 115-124.

San, İ. (1999). Türkiye'de yaratıcı drama çalışmalarının dünü ve bugünü. Cumhuriyet ve çocuk. II Ulusal Çocuk Kültürü Kongresi. Ankara: Ankara Üniversitesi Çocuk Kültürü Araştırma ve Uygulama Merkezi Yayınları.

San, İ. (2002). Yaratıcı drama - eğitsel boyutları: Yaratıcı drama/1985-1995/ yazılar. (1. cilt). Ankara: Naturel Kitap Yayınc1lik.

Tompkins, G. E. (1982). Seven Reasons Why Children Should Write Stories. Language Arts, 59(7), 718-21.

Sutherland, J.A.\&Topping, K.J. (1999). Collaborative creative writing in eight-years old: comparing cross-ability fixed role and same-ability reciprocal role pairing. Journal of Research in Reading, 22, 2, 154-179.

\section{EKLER}

EK-1

\section{UYGULAMALARDA YER VERILLEN ETKINLIIKLERE BİR ÖRNEK}

\section{Yaratıcı Dramaya Dayalı Yaratıcı Yazma Grubunda Gerçekleştirilen Örnek Bir Çalışma}

Kullanılan Teknikler: Fotoğraf karesi yapma, Doğaçlama, Gelecekte seçeceği mesleğe ilişkin 15 yıl sonrasina mektup yazma:

\section{(“Büyük Başarı” metnine ilişkin yapılan çalışmalar içerisinde gerçekleştirilmiştir.)}

Öğrencilerden gözlerini kapatmaları, kendilerini rahat bırakmaları istenir (Oldukça sakin bir tonda müzik sesi sınıfa verilir). Bulundukları mekandan sıyrılmaları başka bir dünyaya, kendi geleceklerine gitmeleri söylenir. Gelecekte olmak istedikleri mesleğe ilişkin herhangi bir mekanda olmaları istenir. Giysilerle, eşyalarla, o durumu yaşamaları, mekanın özelliklerini zihinlerinde canlandırmaları belirtilir. Yaklaşık 5-7 dakika süren zihninde canlandırma sürecinden sonra müzik kapatılarak, öğrencilerden oldukça yavaş bir şekilde gözlerini açmaları istenir. Öğrencilerden zihinlerinde canlandırılan mesleğe ilişkin bir resim yapmaları, daha sonra da yanındaki arkadaşları (ikişerli gruplar) ile hayallerindeki mesleklere ilişkin fotoğraf kareleri oluşturmaları istenir. Her iki öğrenci de sırayla düşündükleri ve resmini çizdikleri mesleği fotoğraf karesi olarak sergiler.

İkişerli gruplardan solanda yavaşça yürümeleri istenir (kaset çalarla müzik sesi verilir). Bu gezme anında "müziği kesince en yakınlarındaki diğer ikili grupla kol kola girmeleri” istenir. Böylece dört kişilik gruplar oluşturulur. Öğrencilere şu yönerge verilir: "Çok isteyerek seçtiğiniz, yıllarca eğitimini aldığınız işinizde çalışmak için iş başvurusunda bulundunuz ve başvuru yaptığınız yerden iş görüşmesi için çağrıldınız. Yapacağınız iş görüşmesini canlandırınız (iş görüşmesi ile ilgili ayrıntılar öğrencilere bırakılır)." Gruplar hazır olduktan sonra canlandırmalarını sergilerler. Bütün gruplar oyununu sergiledikten sonra, her öğrenciden bireysel olarak 15 yıl sonrası için "seçeceği mesleği de göz önüne alarak" kendine mektup 
yazması istenir. Öğrencilerin yazdığı mektuplardan bazıları sınıfta okunur. Gelecekte meslek seçiminde neleri dikkate alacakları konusunda konuşulur.

\section{Mektuplardan örnekler:}

Ben şimdi 11 yaşındayım. 15 y1l sonra öğretmen olmuşum. Minik minik öğrencilerim var. Onlarla çok güzel günler geçiriyorum. Ben 11 yaşındayken zaten hep öğretmen olmak isterdim diyorum. Şimdi oldum işte. Okulumu ve öğrencilerimi çok seviyorum. Onlarla çok güzel oyunlar oynuyorum. Ama öğretmen olmak için çok çalışmalıyım. Tuğba

Ben 15 yıl sonra uçan arabalar, motorlar yapmak istiyorum. Bunları yaparak hem kariyerimi yaparım hem de eğlenirim. Yani işimi eğlence olarak yaparım. Hem böylece insanlara yararım dokunur kötü mü? İnsanları araba kadar küçük bir alette uçuracağım. Feyzullah

Ben polis olmak istiyorum. Nerden esti dersiniz? Benim bir dizim var da ordan. Dünya da öyle ekip var mıdır? Ben polisliği hırsız, uyuşturucu, cinayet vb. işlerle uğraşanları hayata döndürmek için istiyorum. Hayatları nasıl kurtarırız dersiniz? Şöyle: Kötü insanları yakalayıp onları eğiterek, ben onların kötü olmasını istemiyorum. Ben kararımdan dönmeyeceğim. Polis olmak istiyorum. Polisliği çok seviyorum. Ceren

Çok heyecanlıyım. Çünkü bir hemşire oldum. İlkokul hatta okula başlamadan önce hayalimdi. İşte bugün oldum. Hastalarla uğraşmak çok güzel bir duygu, onlara bakmak, ilgilenmek... Ama bebeklerde, çocuklarda çok kötü, çünkü iğneyi değdirir değdirmez ağlyyorlar. Nerdeyse benim de ağlayasım geliyor. Geçenlerde bir hasta gelmişti, beyin tümörü olmuş. Çok üzüldüm, ağladım. Şimdiye kadar tüm ameliyatları yenmiş, ama bunu yenemedi. Hastayı ameliyathaneye alınca onu kaybettik. Ailesi çok üzüldü. Neyse inşallah bir daha öyle hastalıklarla karşılaşmam. Hoşça kalın. Büşra

Askerliğimi bitirip polis olacağım. Çatışmaya katılmak istiyorum. Ölürsem vatan sağ olsun. Eğer ben ölürsem bu vatanı öteki polislere bırakırım. Teröristlerin hepsini yakaladıktan sonra hapse atmalarını istiyorum. Ülkemde iyi insanların öldürülmesini istemiyorum. Polis olup bütün teröristleri yakalayacağım. Onur

15 yıl sonra askerliğimi bitirmiş olacağım. Bilgisayar mühendisi olacağım. İnternet cafe de kuracağım. Evleneceğim, çocuğum olacak, bir kızım olmasını istiyorum. Onunla oyun oynayacağım. Mühendis babam var diye benle gurur duyacak. Annem babam da gurur duyacak. Birlikte restorana gideceğiz. Güzel bir evim olsun istiyorum. Rahat yaşamak istiyorum.

\section{Abdullah}


EK-2

YAZI YAZMAYA YÖNELIKK TUTUM ÖLÇEĞİ

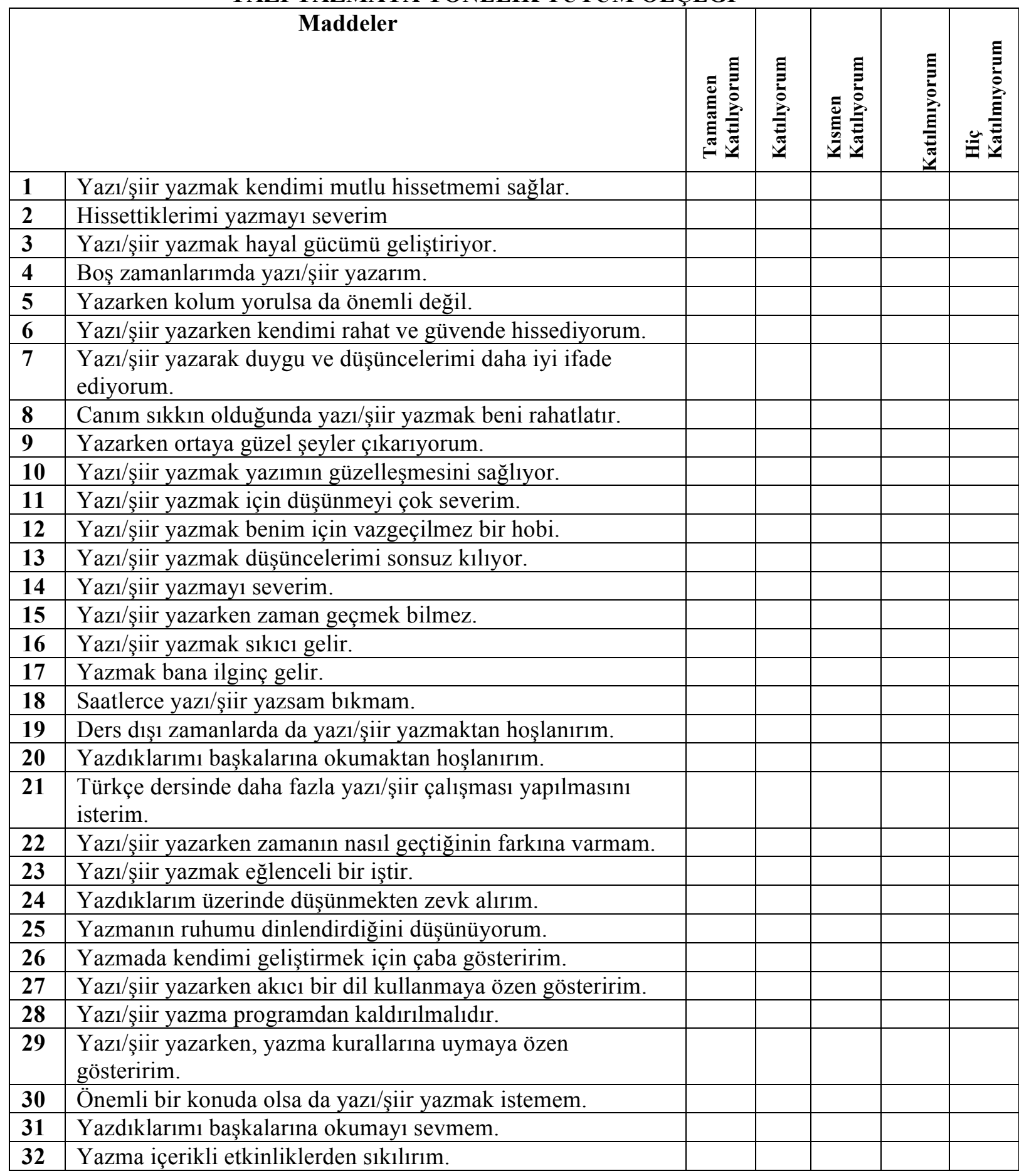




\title{
Summary
}

\section{In Turkish Courses The Effect of Creative Writing Efforts Based on Creative Drama Method on the Writing Attitude}

\author{
Fatma SUSAR KIRMIZI. \\ Pamukkale University

\section{Introduction}

Individuals discover their abilities, increase self-confidence and self-respect, gain the skill of making independent decisions, and prepare for various circumstances by the Creative Drama. The Creative Drama unearths the skills of the creativity and imagination, helping both individual and social development. The Creative Writing Approach which has been parallel by this understanding is another dimension of the study as well. Besides, we should not forget that in the works of Creative Drama, writing also has been used. When there were many forms of using tales, poems and stories, activities such as narration, using the existing story, and developing the creative thinking on the basis of tales.

There are many factors which affect the writing achievement. We cannot explain the strengthening of students' writing motivation only by the method used in the classroom. A powerful inclination for writing is important for students like using the writing skills. A good motivation toward writing needs also a positive attitude toward writing. Interesting subjects may increase the students' writing motivations. Different and authentic writing works are quite effective on the development of the students' thinking skills. These works will affect the students' attitude toward writing in their academic 
lives, too. The aim of this study is to put forward the effect of Creative Writing Works based on the Creative Drama Method on the attitude toward writing.

\begin{abstract}
Method
For researching the sub questions of the study, we used post test, control group experimental design. We carried out this study in Denizli city center in the first (fall) term of 2007-2008 school year at a public primary school with students of middle class origin. 5. In the study with 5th Grade students, there were 1 experimental group and 1 control group. There were $32($ Female $=18$, Male $=14)$ students in the experiment group and $36($ Female $=19$, Male $=18)$ in the control group. We applied the Creative Drama Method to the experiment group, and methods, techniques and activities included Turkish program for 2005-2006 School Year the control group. The study was carried out under the theme of "Novelties and Developments" in six sessions. We accepted 135 minutes (each lesson lasts 45 minutes) in the same day as a session.
\end{abstract}

For the instrument of obtaining data, we used "Evaluation Criteria Form for Writing" (ECFW) developed by the researcher to understand writing attitude of 4-5th Grade students in the primary schools. For pre trial work of the evaluation criteria, we obtained data from 258 students (female $=145$, Male=113). To determine the validity of the structure, factor analysis has been applied to data obtained from the trial work. As a result of the factor analysis, the remainder factor eigenvalues of 34 items differ between 0,50 and 0,86 , and Cronbach Alpha reliability coefficient is 0,90 .

In six sessions, the activities of Creative Drama and Creative Writing have been prepared and applied by the researcher who also trained as a leader. In line with the aim of the study, techniques and activities as rhythm technique, station technique, improvisation, drawing, narration of poems, preparing TV programs have been used in the writing activities. At the end of each session, we tried to evaluate the activity process. There were three separate stages in the plans: 1. Works for Preparation-Warm Up, 2. Animation, and 3. Evaluation-Discussion. 


\section{Findings and Comment}

To answer the lower question of the study, we tried to understand whether there was any significant variance between the experiment group and control group according to the posttests of "Evaluation Criteria Form for Writing." According to the measurement results of the attitude towards writing, we determine a significant variance between posttests of the experiment and control groups in favor of the experiment group. Works done in this group have been effective on developing a positive attitude toward writing. We found a significant variance between pre and posttests of the experiment and control groups. We may say that works done in both group are effective for developing positive attitude toward writing; but the averages obtained from the experiment group are higher.

\section{Conclusion and Discussion}

In the learning experiences of the experiment group, we made use of the group dynamics of the Creative Drama method, and gave place occasionally to individual and group activities. In accordance with the essence of the Creative Drama and Creative Writing, we tried to unearth the creativeness of children in these activities which were based on dreaming and imagination. During the process of activities, the students either individually or as a group have dreamed, played or used different techniques. Completely kept out of to be criticized and to make mistakes, the students freely expressed their own thoughts. During the sessions, the students thought freely and beyond traditional patterns because they knew that they would not be judged for their own thoughts. They expressed themselves and wrote freely. According to the conclusion, we may say that the Creative Writing Works based on the Creative Drama Method have an effect on the developing of a positive attitude toward writing. To develop a positive attitude toward writing, we should give more places to the activities of Creative Writing and Creative Drama in the Curriculum. Besides, the Curriculum should be revised for the sufficiency of the activities of the Creative Writing and Creative Drama. 